\title{
Multinationality-Performance Relationship:
}

\section{A Meta-Analysis}

\author{
Yong Yang • Nigel Driffield
}

(forthcoming management international review, accepted November 2010)

\section{Abstract}

- We conduct a Meta-analysis of 54 papers that study the relationship between multinationality and firm performance. The aim is to understand if any systematic relationships exist between the characteristics of each study and the reported results of linear and curvilinear regressions to examine the multinationality-performance relationship.

- Our main finding, robust to different specifications and to different weights for each observation, is that when analysis is based on non-US data, the reported return to multinationality is higher. However, this relationship for non-US firms is usually U-shaped rather than inverted U-shaped. This indicates that US firms face lower returns to internationalization than other firms but are less likely to incur losses in the early stages of internationalization.

- The findings also highlight the differences that are reported when comparing regression and non-regression based techniques. Our results suggest that in this area regression based analysis is more reliable than say ANOVA or other related approaches.

- Other characteristics that influence the estimated rate of return and its shape across different studies are: the measure of multinationality used; size distribution of the sample; and the use of market-based indicators to measure firm performance. Finally, we find no evidence of publication bias.

Keywords: Meta-Analysis, Multinationality, Performance, Publication Bias.

\section{Authors}

Dr. Yong Yang

Lecturer in International Business and Entrepreneurship

Essex Business School, University of Essex,

Southend-on-Sea, UK

e-mail: yongyang@essex.ac.uk

Prof. Nigel Driffield

Head of Economics and Strategy Group,

Aston Business School, University of Aston,

Birmingham, UK

n.l.driffield@aston.ac.uk 


\section{Introduction}

Multinational firms have opportunities to achieve greater returns from international exploitation of intangible assets. Allied to this are the benefits of internalisation, including economies of scale and scope, and the ability to relocate activities to reduce costs. Further multinationals have mechanisms for more efficient allocation of resources, through the creation of intra-firm markets when intermediate markets are missing. These features of multinationality lower the costs and increase productivity, leading to increased financial performance (Buckley and Casson 1976; Rugman 1986; Dunning 1988; Tallman and Li 1996; Helpman et al. 2004). Conversely, multinational firms may also face liabilities from increased coordination and management costs and cultural diversity, which could be detrimental to firm performance (Zaheer 1995; Kostova and Zaheer 1999; Lu and Beamish 2004). Given its potential relevance, research on the relationship between multinationality and performance (hereafter referred to as MN-Performance) at firm level has grown considerably since the mid-1970s. Recent research focuses on the nonlinearities in the MN-Performance relationship, focusing on the U-shaped relationship initially, but more recently extended to the S shape (Contractor et al.2003; Contractor 2007) performance relationship. This suggests an initially negative MN-Performance relationship due to organizational costs and complexity associated with overseas expansion outweighing benefits, before the positive returns of foreign direct investment are realized (Qian 1997; Ruigrok and Wagner 2003). Other studies find an inverted U-shaped relationship which suggests that multinationality is associated with positive returns but, beyond an optimal desirable level, it has detrimental effect on performance. The reasons for this downturn in returns are due to the liabilities associated with overseas expansion and the difficulties of organizational coordination across different cultures and legal environments (Gomes and Ramaswamy 1999; Qian et al. 2008).

Despite the large and impassioned debate concerning the MN-Performance relationship, particularly the importance of nonlinearities, the empirical literature provides a rather unclear picture. In part this relates to the sampling and 
methodological heterogeneity across studies (Li 2007). Where a literature, beset by heterogeneity, but focusing on a given issue provides rather contrasting findings meta-analysis can make the picture much clearer. Our paper follows the Meta-analysis approach used by Stanley and Jarrell (1989), Card and Krueger (1995), Ashenfelter et al. (1999), Görg and Stobl (2001), Pereira and Martins (2004), Bausch and Krist (2007) and Martins and Yang (2009) and estimate a Meta-analysis regression (MAR).

The analysis therefore proceeds in a number of stages. The first and main aim is to the empirical literature concerned with $\mathrm{MN}$-Performance relationship understand if any systematic relationships exist between the characteristics of each study and its estimated result of linear and curvilinear MN-Performance relationships. For such a tightly defined literature, it is perhaps surprising the extent to which the studies vary. For example, studies vary not only by the timeframe considered, but also by country coverage, the use of regression analysis, the measure of multinationality used, size distribution of the sample, the measure of firm performance. The second aim of Meta analysis is to examine the possibility of publication bias. This relates to the high level of speculation that journal editors potentially favour studies that reach significant results to the detriment of papers which find no significant relationships. Such selection process would result in a non-representative set of evidence, thus biasing one's inference concerning the magnitude of the effect of interest.

Surveying more than 50 papers and conducting different robustness tests, we are able to identify some clear patterns concerning the study features that can systematically predict the outcomes of different studies. In particular, we find that when firm samples are outside the USA the return to multinationality is higher. However, the shape of curvilinear outcome for non-US firms is usually U-shaped rather than inverted U-shaped. This is an important result from the point of view of analysis of globalization and economic policy in general. US firms face lower returns than other groups of firms but are less likely to face losses in the early stages of internationalization. We also find the financial crisis does not have direct impact on the return to multinationality, and more recent samples find lower rates of return and an inverted U-shape. Other significant characteristics that influence the estimated rate 
of return and its shape across studies are: the use of regression analysis; the measure of multinationality used; size distribution of the sample; and the use of market-based indicators to measure firm performance. Moreover, we do not find evidence of publication bias.

The next Section describes in more detail the econometric approach undertaken in the studies that we analyze and then explain our own econometric methodology. Section 3 describes all the studies included in this paper, while section 4 analyzes the main findings. Finally, section 5 concludes.

\section{Methodology}

\section{Assessing the linear MN-Performance relationship}

Our Meta analysis of linear MN-Performance relationship is primarily concerned with firm-level studies that estimate equations of the following type:

$$
Y_{i t}=\beta M_{i t}+\lambda X_{i t}+\gamma_{t}+e_{i t}
$$

where $Y_{i t}$ is the accounting-based or market-based firm performance of firm $i$ for a given period $t . \quad M_{i t}$ refers to the degree of firm multinationality over the same period. The equation may also include other control variables, such as firm characteristics $\left(X_{i t}\right)$, and/or controls for business cycle effects $\left(\gamma_{t}\right)$.

The key parameter of interest for our analysis is $\beta$, which indicates the strength of the MN-Performance relationship. We then relate the estimates of $\beta$ reported by the different studies to the characteristics of that study. Thus, the main results from meta-analysis are obtained by estimating an Eq 2, in which $\hat{\beta}_{j}$ is the reported estimate of the $J^{\text {th }}$ study and $Z_{j k}$ are the variables that measure the characteristics of that same estimate and that were described above.

$$
\hat{\beta}_{j}=\alpha_{0}+\sum_{k=1}^{K} \alpha_{k} Z_{j k}+e_{j}
$$

$Z_{j k}$ contains the dimensions that are of particular interest which may influence the value of $\beta$ obtained in a systematic (non-random) way. The dimensions we 
considered are:

Financial Crisis: We create a dummy variable that takes value one if the survey year of the paper is in the period of financial crisis or one year after, otherwise zero. The timing of financial crisis is taken from Laeven and Valencia (2008). Given the current global financial crisis, there is now serious concern about its impact on MNE those who rely on overseas activity as their engine of growth. Hence it is important to know whether there was any significant knock-on effect on the return to multinationality during a previous crisis in the sample countries covered in different studies being considered in the meta-analysis here.

Country of origin: Differences in country of origin may tend to be systematically related to the MN-Performance relationship. An overwhelming majority (more than $70 \%$ ) of studies is based on US data, while the remaining studies are from other countries. This may bias results for two reasons. First, the USA is a large economy where the exploitation of proprietary advantages domestically is as likely to generate superior returns as their exploitation through international diversification. Firms from outside the USA are less likely to enjoy such scale economies from their domestic markets. The value of internationalizing is likely to be correspondingly higher. Secondly, it is well documented that firms from Asia have used internationalization abroad as a strategy to learn from overseas clients or competitors. We examine the role of country of origin by introducing a dummy variable that is equal to one if the study does not sample from the USA.

Estimation method: The estimation method may also have an impact upon the size of $\beta$. While the standard approach to the estimation of (1) is regression analysis, some papers compare means of performance based on ANOVA methods or t-tests across firms with different degrees of multinationality. One may argue that the latter (non-regression) methods may lead to biased estimates as they do not take account of cross-correlations between multinationality and other variables. In order to take account of this factor we create a dummy variable that takes value one if the analysis uses non-regression methods. 
Measure of multinationality: The most common approach to measuring the degree of multinationality is the ratio of foreign to total sales (FSTS). Some studies use other measures, such as the ratio of foreign to total assets, the number of overseas subsidiaries and the number of overseas countries. The MN-Performance relationship may be influenced by the measure of multinationality used in the study. To control for this possibility we create a dummy variable equal to one if the study does not use the FSTS to measure multinationality.

Sample heterogeneity: Most studies draw on large firms, whereas some studies sample small firms, and this may lead to different results. There are numerous reasons for this. Firstly, following the standard resource-based view arguments, large firms may be better placed to identify and execute investment opportunities, with a wider range of alternative strategies and financial instruments at their disposal. Small firms however, building on the recent "born global" are perhaps more "niche" firms, and likely to have overseas activities concentrated in a few locations. Large firms have the possibility to internationalize often because of slack resources and other ownership advantages which allow them to exploit internationalization more effectively. Perhaps for these reasons much of the literature in this area focuses on large firms.

However, by including in our analysis some papers that focus on small firms, this adds a further dimension. As the wider discussion on born globals indicates, small and medium size firms choose to enter a limited number of foreign markets, seeking fast growth in niche markets internationally. Due to a lack of internal resources, SMEs are more likely to rely on secondary data, and specialized external market research activities in order to select suitable markets abroad, and as Brouthers and Nakos (2005) point out, this high level of selectivity may lead to earlier, and faster rates of performance growth than experienced by larger firms. Further, small firms are likely to be further away from the frontier of technological knowledge, but may learn more from overseas clients or competitors which could be reflected in their long term performance.

Large firms, typically original in the US and Europe, are more likely to at the later stage of internationalization. However, along with globalisation pace, overseas 
expansion is no longer the domain of large firms. Firms from developing countries in particular from China, India and Singapore have been observed to internationalize, and at the early stage of internationalization development (Pangarkar 2008). We argue the MN-Performance relationship may be moderated by the size of firms sampled in the study. To investigate this possibility we create a dummy variable taking value one for estimates based on large firms.

Measure of performance: The most common indicators used to measure firm performance are return on sales/equity/assets (accounting-based indicators) or market capitalization/Tobin's Q (market-based indicators). Accounting-based indicators are likely to be related to the existing size of firms and capture short-term performance, while market-based indicators are related to valuation of the firm by the market according to long-term performance. To investigate the influence of performance measurement on the $\mathrm{MN}$-performance relationship, we create a dummy variable that takes value one if the reported estimate is based upon a market-based indicator.

Time period: The MN-Performance relationship is not necessarily constant across years, particularly as globalization has profoundly affected a great number of countries. This process of widening globalization in the last two decades may mean that multinational firms have become a larger, more similar group of firms, thus eroding performance advantages that are presumably generated by overseas investment. To test this possibility we construct a variable which measures the average year of the data sample underpinning each estimate. Thus, for a study using data between 1995 and 2000, the time period variable would take the value 1997.5.

All the above seven characteristics can be obtained from information reported in the papers studied. We also use the square root of number of observations and reported standard error of the estimate as control variables. Controlling for differences in standard error is important to prevent bias due to larger but insignificant point estimates dominating smaller but significant ones. However, this can only be done for regression-based studies, meaning that where this variable is included, we can only use a sub sample of the data.

Meta-analysis typically treats all studies as equally important. As an additional 
consideration however, one may wish to attach greater importance to papers published in comparatively higher ranked journals. As an additional estimation, we attribute different weights to each estimate, depending on the ranking of the journal in which the paper and the estimate appear. In particular, we consider two different rankings: those listed in the Association of Business Schools (ABS) ranking 2008 and a second ranking based on the simple average of Aston 2006, Kent 2005, Cranfield 2005, Durham 2006 and citation impact rankings ${ }^{1}$. It ranks journals from 1 to 4 (4 being the highest). For those publications with no ranking, we assign a weight of 0.5 . A second correction is that some papers present more estimates than others. In order to prevent a small number of papers with large numbers of estimates from dominating the findings disproportionately, this study divides the weight of the ranking (if used) by the number of estimates in the paper. Our benchmark results are based on an unweighted analysis of the estimates.

\section{Assessing the curvilinear MN-Performance relationships}

Our Meta-analysis on the curvilinear MN-Performance relationships is primarily concerned with firm-level studies using equations of the following type: Eq. 3, in which $M^{2}{ }_{i t}$ refers to the square of degree of multinationality of firm $i$ for a given period $t$; other variables are the same as those in Eq. 1.

$$
Y_{i t}=\beta_{1} M_{i t}+\beta_{2} M^{2}{ }_{i t}+\lambda X_{i t}+\gamma_{t}+e_{i t}
$$

In our analysis, we relate the shape of curvilinear outcome reported by the different studies to the characteristics of that study. Thus, the main results from meta-analysis on curvilinear relationships are obtained by estimating the probit Eq.4.

$$
\operatorname{Pr}\left(\text { Shâpe }_{j} \neq 0 \mid Z_{j k}\right)=\Phi\left(\alpha_{0}+\sum_{k=1}^{K} \alpha_{k} Z_{j k}+e_{j}\right)
$$

, in which Shape is the reported outcome taking value one if it indicates the inverted U-shaped curve. $Z_{j k}$ contain the dimensions that are of particular interest which may influence the shape of curvilinear outcome, and they are the same as those 
in Eq. 2. $\Phi$ is the standard cumulative normal distribution of Shâpe, and could be calculated by $\alpha_{0}+\sum_{k=1}^{K} \alpha_{k} * \bar{Z}$. In addition, we also have a control for the square root of the number of observations and divide the weight of the journal ranking (if using one) by the number of estimates in the paper in our Meta-analysis regression. In practice, rather than reporting the coefficients $\alpha_{k}$, we report the marginal effect in our analysis ${ }^{2}$.

\section{Publication Bias}

Following the Meta-analysis literature (Card and Krueger 1995, Görg and Strobl 2001), this paper also tests whether there is a publication bias in research concerning MN-Performance relationship. One may expect that studies are more likely to be published if they obtain significant effects.

The standard test for publication bias, following (Card and Krueger 1995), search for evidence of publication bias in our published paper sample by regressing the $t$-ratio of each estimate on the same set of controls as in equation 2 plus a control for the square root of the number of observations used for that same estimate. The rationale for this analysis is that in the absence of publication bias, the studies with a relatively small number of observations are more likely to be published if they have a high $t$-ratio. As Card and Krueger (1995) put it, 'If studies are only published if they achieve a $t$-ratio of 2 or more, and if researchers choose their specification in part to achieve statistically significant results, then the early studies [in the minimum-wage literature] may tend to have a high $t$-ratio despite their small samples.' (page 239).

\section{Descriptive statistics}

We identified 70 studies on MN-Performance relationships that fall within the common methodology defined above ${ }^{3}$. In order to focus our analysis on comparable studies, we consider only those that estimate equations as in Eq. 1. There are a small number of studies that do implement analysis as those of Eq. 1 but are not considered 
in our paper because they are not sufficiently explicit in explaining the data and methods used.

After restricting the studies to those using Eq.1 and giving sufficient information for our analysis, we are left with 51 studies on the linear MN-Performance relationship, 46 of which are published in academic journals and 5 are working papers. Curvilinear MN-Performance relationships have attracted much attention and controversy in recent years, and we found 16 studies on this topic - 15 published in academic journals and one working paper. Table 1,2 and 3 list the papers used in our Meta-analysis regression, alongside some of their main study characteristics and journal weightings mentioned in the previous section. In addition, many papers present more than one estimate of MN-Performance relationship; we list the average estimate of each study as mentioned in Eq. 1 and the average reported shape of curvilinear outcomes as mentioned in Eq. 3.

Table 4 summarizes the main features of our data set and describes the 315 estimates included in our analysis on the linear MN-performance relationship, of which $16 \%$ are based on a country in a time of crisis. $26 \%$ draw on firms outside the USA; 59\% use market-based performance; 50\% use FSTS to measure multinationality; $7 \%$ of all estimates implement non-regression analysis; and $43 \%$ are restricted to large firm samples. The average year of survey is 1988 and the average number of observations in each sample is around 2631. In addition, this table also describes the 55 estimates on the curvilinear MN-performance relationship, of which $36 \%$ an inverted U-shaped curve; of which $46 \%$ draw on firms outside the USA; $11 \%$ use market-based performance; $56 \%$ use FSTS to measure multinationality; and $71 \%$ are restricted to large firm samples. The average year of survey is 1994 and the average number of observations in each sample is around 1413.

\section{Results}

The main results, based on the estimation of Eq. 2 and Eq. 4, are presented in Tables 5 and 6, respectively. In columns 1 and 2, no weight is assigned to each estimate, while 
the remaining columns assign separate weights to different papers, depending on the ranking of the journal in which the paper was published.

\section{The linear MN-Performance relationship}

Table 5 presents the baseline regression results, and contrasts the results controlling for differences in standard error or not .The results without the control for variation in standard errors (columns 1-3) in show that work based on data at the time of a financial crisis tend to generate higher estimates of MN-Performance relationship (significant level at least at 5\% in weighted columns). This suggests that researchers are finding that, at times of crisis, firms that engage in FDI (perhaps seeking to diversify away from the crisis at home) do better than those which do not. Non-United States firms tend to generate higher estimates of MN-Performance relationship (significant level at least at 5\% in all columns). The non-regression estimation method, however, tends to have lower estimates (significant level at 5\% in all columns). The MN-Performance relationship is negatively correlated with the multinationality measurement if the paper uses the ratio of foreign sales to total sales to measure the multinationality rather than foreign capital aspects (significant level at 5\% in all weighted columns). When firm performance is measured by market-based indicators, it tends to produce lower estimates (significant level at $10 \%$ in the unweighted column). Finally, the survey year of firm samples tends to have a negative effect upon MN-Performance relationship with significant levels at 5\% in all columns.

Columns 4-6 of table 5 augment the analysis, by including and addition covariate, the standard error of the estimate of $\beta$. Once on controls for the degree of significance in this way we find that financial crisis now does not affect the return to multinationality, and we believe the significant impact from financial crisis without control for standard error in the first three columns of this table is biased. This suggests that studies carried out at the time of crisis over-state the returns to multinationality. After this, the single and most interesting result that appears to be generally unchanged across the different weights, at least all columns are significant, concerns the role of country of origin. Across all columns, firms based on non-United 
States display higher estimates of the MN-Performance relationship. In fact, the estimate ranges between 0.368 and 0.465 and all coefficients are significant.

Considering now the remaining study characteristics included in our analysis, we find more covariates are significantly related to the MN-Performance relationship after we control for standard error of the estimates. It shows that the estimates based on multinationality by foreign sales measurement tend to produce negative impacts (although it is only significant in one weighted column), while the estimates based on large firm samples and market-based performance now tend to lead to larger (more negative) impacts, and year of survey remains negative. Most of them are significant at least at $5 \%$ level.

Consistent with the main findings of Bausch and Krist (2007) and a recent survey paper Li (2007), we attribute much of the variation in the reported importance of nonlinearity in the MN-P relationship to sampling and methodological heterogeneity across the studies, although two papers conduct different Meta analysis approaches. This is informative because our paper follows Meta analysis approach by Card and Krueger (1995) and Görg and Stobl (2001), while Bausch and Krist (2007) follows Meta analytical techniques developed by Hunter and Schmidt (1990) and Hunter et al. (1982).

In contrast to Bausch and Krist (2007), who limit their analysis to a set of five variables believed to impact on the MN-P relationship, we consider a wider set of variables which explain the variation in the estimated MN-Performance relationship across different studies, including measures of multinationality and performance, time period, and financial crisis. Moreover, the Meta analysis work on this literature is refined in our paper in two aspects. Firstly, we consider an issue of some debate currently, the issue of curvilinearity in the relationship between multinationality and performance. We address this by analysing how sampling and methodological heterogeneity influence results of the tests for a curvilinear relationship. Second, following the Meta analysis literature, we also test whether there is publication bias in the MN-performance relationship literature. We present results on these two points in next two sub-sections. 


\section{The curvilinear MN-Performance relationships}

Table 6 then presents the results of our further analysis, focusing on the sub-sample of studies that allow for nonlinearity in the relationship. The results ${ }^{4}$ in columns 1-3 show that papers sampling non-United States firms tend to show a U-shaped MN-Performance relationship (significant at $1 \%$ in all columns). We also find other characteristics that influence the shape of curvilinear outcome: the measure of multinationality used; size distribution of the sample; the use of performance measurement; and time period of firm samples. As shown in this table, coefficients on time period are positive and only significant in the weighted column, which indicate that papers based on recent sample published in higher journals are more likely to show inverted U-shaped curve of MN-Performance relationship. Equally, papers based on analysis of large firms and published in higher ranked journals are more likely to find a U-shaped relationship.

We seek to extend the existing literature in one further way. We exploit the fact that most papers consider the degree of multinationality to have a normal distribution, and indeed this assumption is explicit in the derivation and estimation of equation 3 using standard regression methods. If the degree of multinationality can be characterized as a normal distribution, then one can make two further inferences. Firstly, that the degree of multinationality corresponding to the turning point in the $U$ shaped relationship can be calculated as $\left[-\beta_{1} / 2 \beta_{1}\right]$. Secondly, that $95 \%$ of multinationality distribution lies within two standard deviations from the mean of multinationality. As such, the value of multinationality representing the turning point must lie within two standard deviations from the mean, otherwise it is an outlier. We use these two properties to assess the estimates reported in the paper sample if the points of multinationality identified emerge as outliers when a normal distribution is assumed. We then compare the analysis of the full sample (columns 1-3 of table 6) with an analysis of only those papers that do not suggest that their inferred turning point lies further than two standard deviations from the mean. This limits the number of papers to 35, but we report this analysis in columns 4-6 of table 6 . 
Once we include the normality condition in our analysis, it is notable that that papers based on non-US data are much more likely to find the U-shaped MN-Performance curvilinear relationship. This suggests that for firms outside the USA the organizational costs and complexity associated with environmental uncertainty and foreignness and coordination and management tend to outweigh the advantages in the early stages of overseas expansion, while this does not apply to US firms. This is an interesting finding in the context of the fast growing "born globals" literature. Much of the early analysis was conducted for non-US firms, for example Autio et al (2002) or Moen and Servais, (2002), and finds that such businesses first emerged in countries with small domestic markets, and once they could no longer expand domestically, they internationalised quickly. In contrast, Knight and Cavusgil (2004), highlight the importance of innovation in these firms in a US context. As such, US firms that internationalise do better in the early stages than non US firms, possibly because the pressures to internationalise are less, while the benefits through the ability to exploit a unique technology are greater.

Considering now the remaining study characteristics included in our analysis, we find the measure of multinationality used and size distribution of the sample are significantly related to the shape of curvilinear outcome after we consider the normality assumption. The use of non-FSTS to measure multinationality is more likely to produce the U-shaped curve, while large firms tend to show an inverted U-shape. Although the results in columns 2 and 3 indicate that large firm samples tend to generate U-shapes, we believe they are misleading results as we do not consider the normality assumption. We also find more recent samples remain an inverted U-shape (although only significant in one weighted column).

Next, we consider S-shaped models MN-Performance. Recently, the literature has sought to test a three stage model of firm development, see for example Contractor et al. (2003), Lu and Beamish (2004), Thomas and Eden (2004), Ruigrok et al.( 2007), Andersen (2008). This posits a three stage model of multinationality and performance. This literature suggests that multinational firms experience an initial performance downturn consistent with low levels of multinationality, followed by an increasing 
performance at moderate degree of multinationality, and eventually a second and final performance downturn with high levels of multinationality. The hypothesis of an $\mathrm{S}$ shaped relationship is then tested with the use of a higher term, the cube of multinationality, augmenting the squared term.

In order to consider S-shape curve in our Meta analysis, we therefore in table 7 introduce a dummy for those papers which include a cubic term. As table 7 illustrates, the sign and significance of the variables in table 6 are robust to the addition of this variable. Papers based on US firm samples still tend to show an inverted U-shaped MN-Performance relationship and results are significant at $1 \%$ in all columns. We again find the use of FSTS as multinationality measure and large firm sample are more likely to show inverted U-shapes, and all of them are at significant level at least $10 \%$. The coefficients on the cubic dummy variable are not significant. This suggests that the limited number of papers that employ the cubic specification to test the S-shaped hypothesis do not generate significantly different results in terms of the $U$ or inverted $U$ relationship between MN-Performance. This illustrates that while the $\mathrm{s}$ shaped hypothesis is worthy of further investigation, it does not change the findings of the Meta analysis of multinationality squared.

\section{Publication Bias}

The results from testing publication bias are presented in Table 8 . We regress the $t$-ratio of each estimate on the same set of controls as in equation 2 plus a control for the square root of the number of observations used for that same estimate. A positive and significant relationship between sample size and the $t$-ratio indicates that there is no evidence of publication bias. However, two papers (Denis, Denis and Yost, 2002; Lu and Beamish, 2004), sampling a large number of firms, show $t$-ratios of more than 10 and are located at the upper right corner -- quite far from other papers in figure 1. When these two papers are removed from the analysis to have a clear figure of publication bias, we actually find a positive relationship between the number of observations and the $t$-ratio in the figure. The study therefore concludes that there is no evidence of publication bias in the literature concerning MN-Performance 
relationships.

\section{Conclusions}

We conduct a Meta-analysis of more than 50 papers on MN-Performance relationships. Overall, our results emphasize that returns to multinationality are higher for firms outside the USA, a finding robust to a large set of different specifications. Non-US firms face the constraints of limited size of the domestic market and possible shortages of resources, while in the exploitation of proprietary advantages domestically US firms potentially yield superior returns than through international diversification. This feature in the analysis also impacts on the shape of curvilinear relationship, with our analysis indicating that non-US firms typically show a U-shaped MN-performance relationship. This means they tend to suffer initial losses before the returns to multinationality can be realized. US firms face lower returns than other groups of firms but are less likely to face losses in the early stages of internationalization - thus these findings also explain why US firms are more likely to go abroad.

The analysis of studies that focus on firms in a time of crisis are particularly informative, given the recent global financial crisis. Our findings indicate that the returns to multinationality are not affected in the periods of crisis. Multinational firms may find it harder to access the necessary working capital and long-term investment financing at a time of crisis, but the same may be said of domestic expansion, such that the differential between foreign and domestic investment returns does not differ across crisis.

Interestingly, the survey year is another important factor in explaining differences in the estimated MN-Performance relationship. We find that more recent samples have lower rates of return to multinationality. This suggests that with globalization comes a wider set of countries in which a firm can invest, such that the incremental gains from expanding into one more country is reduced. Equally, with firms from a wider range of countries engaging in FDI, then the performance advantage that is generated by 
overseas investment may have been eroded. The other possible reason is the growth of different entry modes, such as outsourcing, which may affect the return to multinationality.

Finally, we find no evidence of publication bias in the research on multinationality and firm performance. On a more technical level, we also suggest that care should be taken when comparing estimates from papers that adopt different methodologies: non-regression analysis and estimates based on market-based performance or foreign sales to measure multinationality reduce the apparent strength of the MN-Performance relationship, as does the use of data based on samples of large firms only. This also influences the nature of the predicted curvilinear shape. We also found some papers on curvilinear relationships to be inconsistent, in terms of the apparent turning points, and the distribution of multinationality. This suggests that such studies, or future studies reporting similar results warrant further examination, both from an empirical perspective, and from a theoretical one, in terms of how it is possible to generalize from such studies. The purpose of this Meta analysis has been to examine some of the reported differences in the relationship between multinationality and performance, and to highlight the large degree of heterogeneity in this literature. In particular, it highlights how international business as a discipline should proceed with caution, when seeking to develop theory in this area from relatively narrow samples, which when taken together yield contrasting results. Our analysis also suggests that future study should pay more serious attention on sampling and methodological differences when comparing findings with other studies in this literature. 


\section{Acknowledgements}

We are very grateful to anonymous referees of this journal for their constructive comments on an earlier version of this paper. The authors gratefully acknowledge the financial support from the ESRC under RES-062-23-0986. We also thank Stephen Tallman, Suma Athreye, Pedro Martins, Teresa da Silva Lopes, Sushanta Mallick, Richard Kneller and the anonymous referees careful reading of my paper and insightful comments and suggestions for improvement, particularly the issue of curvilinearity. We also thank Simon Mohun, Tomasz Mickiewicz, Yadong Luo, and participants at Workshop 2008 at Queen Mary, University of London and AIB 2010 conference at Rio de Janeiro, for helpful comments. All errors are our own.

\section{Endnotes}

1. This ranking information is available in Harvey et al (2008).

2. This reports the marginal effect of the outcome probability to be an inverted U-shape curve with respect to study characteristics $Z_{j k}$.

3. It is important to emphasize that there are a group of studies used other dependent variables, such as innovation, patent and technical efficiency. However, in order to focus our analysis on comparable studies, we consider only those that use accounting/market-based performance.

4. As we found that financial crisis does not affect the return to multinationality in table 5 , we do not include this variable in table 6 .

\section{References}

AL-Obaidan, A. M., \& Scully, G. W. (1995). The theory and measurement of the net benefits of multinationality: The case of the international petroleum industry. Applied Economics, 27(2), 231-238.

Allen, L., \& Pantzalis, C. (1996). Valuation of the operating flexibility of multinational corporations. Journal of International Business Studies, 27(4), 633-653.

Andersen, J. T. (2005). The performance and risk management implication of multinationality: An industry perspective. SMG Working Paper 10.

Andersen, J. T. (2008). Multinational performance relationship and industry context. SMG Working paper 15 .

Ashenfelter, O., Harmon, C., Oosterbeek, H. (1999). A review of estimates of the schooling/earnings relationship, with tests for publication bias. Labour Economics, 6(4), 453-470.

Autio, E., Heikki, L., Arenius, P. (2002). Emergent "Born Globals": Crafting early and rapid internationalization strategies in technology-based new firms. Helsinki University of Technology Working Paper Series 91-WP-2002-003.

Autio, E., \& Sapienza, H. (2000). Comparing Processes and Born Global Perspectives in the international growth of Technology-Based New Firms, Frontiers of Entrepreneurship Research, Center 
for Entrepreneurial Studies, Babson College pp. 413-424.

Bausch, A., \& Krist, M. (2007). The effect of context-related moderators on the internationalization -performance relationship: Evidence from meta-analysis. Management International Review, 47(3), 319-347.

Bodnar, G. M., Tang, C., Weintrop, J. (1999). Both sides of corporate diversification: The value impacts of geographic and industrial diversification. NBER Working Paper 6224.

Brouthers, E. L., \& Nakos, G (2005). The role of systematic international market selection on small firms' export performance. Journal of Small Business Management, 43(4), 363-381

Buckley, P. J., \& Casson, M. (1976). The future of the multinational enterprise. London: Macmillan

Buhner, C. H. (1987). Assessing international diversification of West German corporations. Strategic Management Journal, 8(1), 25-37.

Capar, N., \& Kotabe, M. (2003). The relationship between international diversification and performance in service firms. Journal of International Business Studies, 34(4), 345-355.

Card, D., \& Krueger, A. B. (1995). Time-series minimum-wage studies: A Meta analysis. American Economic Review, 85(2), 238-243.

Castellani, D., \& Zanfei, A. (2007). Internationalisation, innovation and productivity: How do firms differ in Italy?. The World Economy, 30(1), 156-176.

Christophe, S. E., \& Lee, H. (2004). What matters about internationalization: A market-based assessment. Journal of Business Research, 58(5), 636-643.

Christophe, S. E., \& Pfeiffer, J. R. (2002). The valuation of U.S. MNC international operations during the 1990s. Review of Quantitative Finance and Accounting, 18(2), 119-138.

Click, R. W., \& Harrison, P. (2000). Does multinationality matter? Evidence of value destruction in U.S. multinational corporations. Federal Reserve Board, Working paper 21.

Collins, J. M. (1990). A market performance comparison of US firms active in domestic, developed and developing countries. Journal of International Business Studies, 21(2), 271-287.

Contractor, F. J., Kundu, S. K., Hsu, C. C. (2003). A three-stage theory of international expansion: The link between multinationality and performance in the service sector. Journal of International Business Studies, 34(1), 5-18.

Contractor, F. J. (2007). Is international business good for companies? The evolutionary or multi-stage theory of internationalization vs. the transaction cost perspective. Management International Review, 47(3), 453-475

Dastidar, P. (2002). The effect of pure multinational diversification on firm value. AIB 2002 Annual Meeting Puerto Rico.

Delios, A., \& Beamish, P. W. (1999). Geographic scope, product diversification, and the corporate performance of Japanese firms. Strategic Management Journal, 20(8), 711-727.

Denis, D. J., Denis, D. K., Yost, K. (2002). Global diversification, industrial diversification, and firm Value. The Journal of Finance, 57(5), 1951-1979.

Doukas, J., Pantzalis, C., Kim, S. (1999). Intangible assets and the network structure of MNCs. Journal of International Financial Management Accounting, 10(1), 1-35.

Dunning, J. H. (1988). The theory of international production. International Trade Journal, 31(1), 21-46.

Geringer, J. M., Beamish, P. W., DaCosta, R. C. (1989). Diversification strategy and internationalization: Implications for MNE performance. Strategic Management Journal, 10(2), 109-119. 
Geringer, J. M., Tallman, S., Olsen, D. M. (2000). Product and international diversification among Japanese multinational firms. Strategic Management Journal, 21(1), 51-80.

Goerzen, A., \& Beamish, P. W. (2003). Geographic scope and multinational enterprise performance. Strategic Management Journal, 24(13), 1289-1306.

Gomes, L., \& Ramaswamy, K. (1999). An empirical examination of the form of the relationship between multinationality and performance. Journal of International Business Studies, 30(1), 173-187.

Gorg, H., \& Strobl, E. (2001). Multinational companies and productivity spillovers: A meta-analysis. Economic Journal, 111(475), F723-739.

Grant, R. M. (1987). Multinationality and performance among British manufacturing companies. Journal of International Business Studies, 18(3), 79-89.

Grant, R. M., Jammine, A. P., Thomas, H. (1988). Diversity, diversification, and profitability among British manufacturing companies. Academy of Management Journal, 31(4), 771-801.

Harvey, C., Morris, H. \& Kelley, A. (2008). Academic Journal Quality Guide, Available at http://www.the-abs.org.uk.

Helpman, E., Melitz, M. J., Yeaple, S. R. (2004). Export versus FDI with heterogeneous firms. American Economic Review, 94(1), 300-316.

Hitt, M. A., Hoskisson, R. E., Kim, H. (1997). International diversification: Effects on innovation and firm performance in product-diversified firms. The Academy of Management Journal, 40(4), 767-798.

Hitt, M. A., Uhlenbruck, K., Shimizu, K. (2006). The importance of resources in the internationalization of professional service firms: the good, the bad, and the ugly. The Academy of Management Journal, 49(6), 1137-1157.

Hunter, J. E., \& Schmidt, F. L (1990). Methods of Meta-analysis: Correcting error and bias in research findings. Newbury Park, CA: Sage

Hunter, J. E., Schmidt, F. L., Jackson, G. B. (1982). Meta-analysis: Cumulating research findings across studies. Beverly Hills, CA: Sage

Hughes, J. S., Logue, D. E., Sweeney, R. J. (1975). Corporate international diversification and market assigned measures of risk and diversification. Journal of Financial and Quantitative Analysis 10(4), 651-652.

Kim, W., Hwang, P., Burgers, W. P. (1993). Multinationals' diversification and the risk-return trade-off. Strategic Management Journal, 14(4), 275-286.

Kim, W. J., \& Lyn, E. D. (1986). Excess market value, the multinational corporation and Tobin's q Ratio. Journal of International Business Studies, 17(1), 119-125.

Knight, G.. A., \& Cavusgil, S. T. (2004). Innovation, organizational capabilities, and the born-global Firm. Journal of International Business Studies, 35(2), 124-141

Kostova, T., \& Zaheer, S. (1999). Organizational legitimacy under conditions of complexity: the case of the multinational enterprises. Academy of Management Review, 24(1), 64-81.

Kotabe, M., Srinivasan, S. S., Aulakh, P. S. (2002). Multinationality and firm performance: the moderating role of RD and marketing capabilities. Journal of International Business Studies, 33(1), 79-97.

Laeven, L., \& Valencia, F. (2008). Systemic banking crises: A new database, Available at http://www.imf.org/external/pubs/cat/longres.cfm?sk=22345.

Li, L. (2005). Is regional strategy more effective than global strategy in the US service industries?. 
Management International Review, 45(1), 37-57

Li, L. (2007). Multinationality and performance: A synthetic review and research agenda.

International Journal of Management Reviews, 9(2), 117-139.

Li, L., \& Qian, G.. (2005). Dimensions of international diversification: the joint effects on firm

Performance. Journal of Global Marketing, 18(3/4), 7-35.

Lu, J. W., \& Beamish, P. W. (2001). The internationalization and performance of SMEs. Strategic Management Journal, 22(6/7), 565-586.

Lu, J. W., \& Beamish, P. W. (2004). International diversification and firm performance: The s-curve Hypothesis. The Academy of Management Journal, 47(4), 598-609.

Martins, P. S., \& Yang, Y. (2009). The impact of exporting on firm productivity: A meta-analysis. Review of World Economy, 145(3), 431-445.

Michel, A., \& Shaked, I. (1986). Multinational corporations vs. domestic corporations: financial performance and characteristics. Journal of International Business Studies, 17(3), 89-100.

Mishra, C. S., \& Gobeli, D. H. (1998). Managerial incentives, internalization, and market valuation of multinational firms. Journal of International Business Studies, 29(3), 583-598.

Morck, R., \& Yeung, B. (1991). Why investors value multinationality. Journal of Business, 64(2), 165-187.

Moen, O., \& Servais, P. (2002). Born global or gradual global? Examining the export behavior of small and medium-sized enterprises. Journal of International Marketing, 10(3): 49-72.

Pangarkar, N. (2008). Internationalization and performance of small- and medium-sized enterprises. Journal of World Business, 43(4), 475-485.

Pantzalis, C. (2001). Does location matter? An empirical analysis of geographic scope and MNC market valuation. Journal of International Business Studies, 32(1), 133-155.

Pereira, P. T., \& Martins, P. S. (2004). Returns to education and wage equations. Applied Economics, $36(6), 525-531$.

Qian, G.. (1997). Assessing product-market diversification of U.S. firms. Management International Review, 37(2), 127-149.

Qian, G.. (1998). Determinants of profit performance for the largest U.S. firms 1981-92. Multinational Business Review, 6(2), 44-51.

Qian, G.. (2002). Multinationality, product diversification, and profitability of US emerging and medium-sized enterprises. Journal of Business Venturing, 17(6), 611-633.

Qian, G, M., Li, L., Li, J., Qian, Z. M. (2008). Regional diversification and firm performance. Journal of International Business Studies, 39(2), 197-214.

Ramirez-Aleson, M., \& Espitia-Escuer, M. A. (2001). The effect of international diversification strategy on the performance of Spanish-based firms during the period 1991-1995. Management International Review, 41(3), 291-315.

Rugman, A. M. (1986). New theories of the multinational enterprise: an assessment of internalization Theory. Bulletin of Economic Research, 38(2), 101-118.

Ruigrok, W., Amann, W., Wagner, H. (2007). The internationalization-performance relationship at Swiss firms: A test of the s-shape and extreme degree of internationalization. Management International Review, 47(3), 349-368.

Ruigrok, W., \& Wagner, H. (2003). Internationalization and performance: An organizational learning Perspective. Management International Review, 43(1), 63-84.

Sambharya, R. B. (1995). The combined effect of international diversification and product 
diversification strategies on the performance of US-based multinational corporations. Management International Review, 35(3), 197-213.

Severn, A. K., \& Laurence, M. M. (1974). Direct investment, research intensity, and profitability. Journal of Financial and Quantitative Analysis, 9(2), 181-190.

Shaked, I. (1986). Are multinational corporations safer? Journal of International Business Studies, 17(1), 83-106.

Siddharthan, N. S., \& Lall, S. (1982). The recent growth of the largest U.S. multinationals. Oxford Bulletin of Economics and Statistics, 4(1), 1-13.

Soenen, L. A. (1990). Stock market recognition of multinationality. Akron Business and Economic Review, 21(4), 64-73.

Stanley, T., \& Jarrell, S. B. (1989). Meta-regression analysis: A quantitative method of literature Surveys. Journal of Economic Surveys, 3(2), 161-170.

Tallman, S., \& Li, J. (1996). Effects of international diversity and product diversity on the performance of multinational firms. Academy of Management Journal, 39(1), 179-196.

Thomas, D. E., \& Eden, L. (2004). What is the shape of the multinationality-performance relationship?. The Multinational Business Review, 12(1), 89-110.

Zaheer, S. (1995). Overcoming the liability of foreignness. Academy of Management Journal, 38(2), 341-363.

Zahra, S. A., Ireland, R. D., Hitt, M. A. (2000). International expansion by new venture firms: international diversity, mode of market entry, technological learning, and performance. Academy of Management Journal, 43(5), 925-950. 
Fig.1: t-ratios and the square root of number of observations

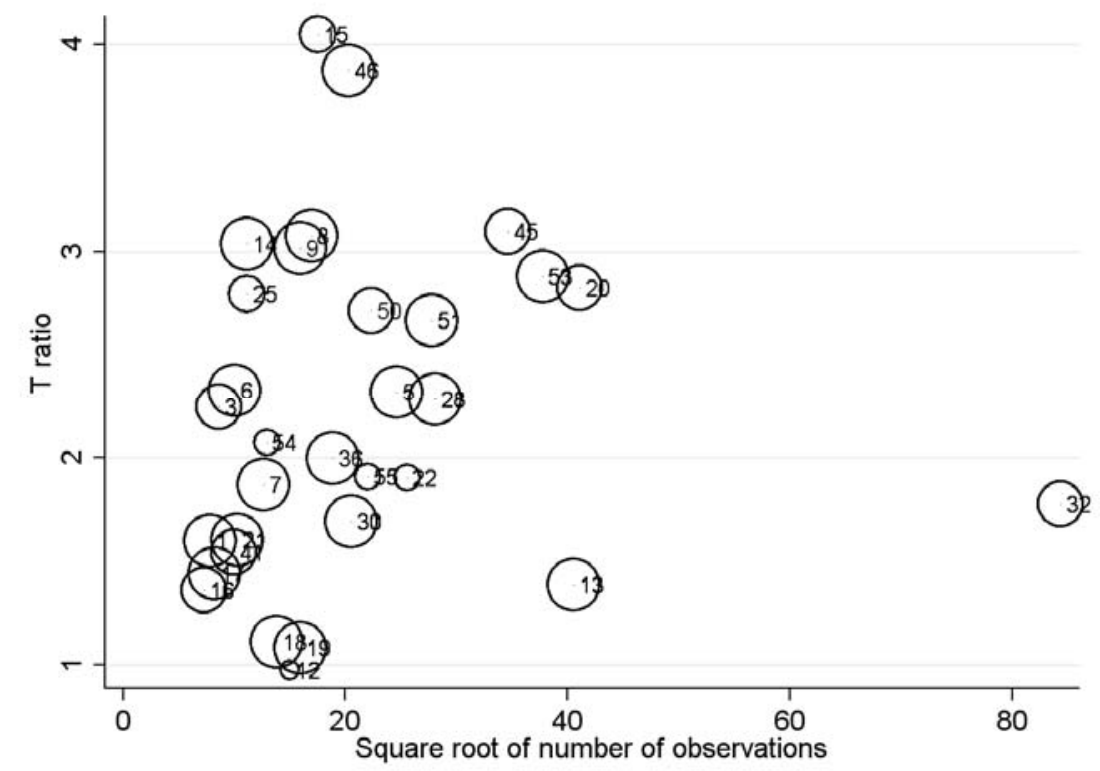

Notes: Size of circle is proportional to the weight of the journal in which the paper was published. The journal weighting used in this figure is derived from the ABS ranking 2008. See text for more details. 
Table 1: List of 51 studies on linear MN-Performance relationships, and some of their characteristics

\begin{tabular}{|c|c|c|c|c|c|c|c|c|c|c|c|c|c|c|}
\hline Paper & Reference & Coef. & Countries & C. & C.O & E.M & $\mathbf{P}$ & S.H & $\mathbf{M}$ & T.P & Obs & W.1 & W.2 & $\mathbf{N}$ \\
\hline 1 & Severn \& Laurence (1974) & 0.87 & US & 0 & 0 & 0 & 0 & 1 & 1 & 1962.5 & 62 & 4 & 3.6 & 4 \\
\hline 2 & Hughes et al. (1975) & 0.04 & US & 0 & 0 & 1 & 1 & 1 & 0 & 1971.5 & 384 & 4 & 3.6 & 1 \\
\hline 3 & Siddharthan \& Lall (1982) & -0.4 & US & 0 & 0 & 0 & 0 & 1 & 0 & 1977.5 & 74 & 3 & 2.6 & 4 \\
\hline 4 & Kim \& Lyn (1986) & 0.00 & US & 0 & 0 & 0 & 0 & 0 & 0.5 & 1976 & 458 & 4 & 3.8 & 2 \\
\hline 5 & Michel \& Shaked (1986) & -0.05 & US & 0 & 0 & 1 & 1 & 1 & 0 & 1979.3 & 656.5 & 4 & 3.8 & 2 \\
\hline 6 & Shaked (1986) & 0.03 & US & 0 & 0 & 1 & 0 & 1 & 0 & 1981 & 101 & 4 & 3.8 & 6 \\
\hline 7 & Buhner (1987) & 4.72 & Germany & 0 & 1 & 0 & 0.3 & 1 & 0 & 1973.5 & 160 & 4 & 3.8 & 3 \\
\hline 9 & Grant et al. (1988) & 5.28 & UK & 0 & 1 & 0 & 0 & 1 & 0 & 1978 & 255 & 4 & 3.8 & 1 \\
\hline 10 & Geringer et al. (1989) & 0.65 & World(1) & 0 & 0.5 & 1 & 0 & 1 & 0 & 1979 & 181 & 4 & 3.8 & 2 \\
\hline 11 & Collins (1990) & -0.09 & US & 0 & 0 & 1 & 1 & 1 & 0 & 1980.5 & 92 & 4 & 3.8 & 2 \\
\hline 12 & Soenen (1990) & 0.04 & US & 0 & 0 & 0 & 1 & 1 & 0.7 & 1982 & 240 & 0.5 & 0.5 & 18 \\
\hline 13 & Morck \& Yeung (1991) & -0.04 & US & 0 & 0 & 0 & 1 & 0 & 1 & 1978 & 1644 & 4 & 3.6 & 36 \\
\hline 14 & Kim et al. (1993) & 0.26 & US & 0 & 0 & 0 & 0 & 1 & 1 & 1984 & 125 & 4 & 3.8 & 1 \\
\hline 15 & AL-Obaidan \& Scully (1995) & -0.01 & World(2) & 0 & 0.6 & 0 & 0 & 1 & 0 & 1979 & 308 & 2 & 2 & 4 \\
\hline 17 & Allen \& Pantzalis (1996) & -0.01 & US & 0 & 0 & 0 & 1 & 0 & 1 & 1991 & 84.4 & 4 & 3.8 & 8 \\
\hline 18 & Tallman \& Li (1996) & 0.03 & US & 0 & 0 & 0 & 0 & 1 & 0.5 & 1987 & 192 & 4 & 3.8 & 2 \\
\hline 19 & Hitt et al. (1997) & 0.04 & US & 1 & 0 & 0 & 0 & 0 & 0.5 & 1989 & 239.5 & 4 & 3.8 & 4 \\
\hline 20 & Qian (1997) & 0.02 & US & 1 & 0 & 1 & 0 & 1 & 1 & 1985.5 & 1690 & 3 & 1.7 & 2 \\
\hline 21 & Mishra \& Gobeli (1998) & 0.34 & US & 1 & 0 & 0 & 1 & 0 & 1 & 1987 & 105 & 4 & 3.8 & 12 \\
\hline 22 & Qian (1998) & 0.06 & US & 1 & 0 & 0 & 0 & 1 & 0 & 1986.5 & 656 & 1 & 0.5 & 6 \\
\hline 23 & Bodnar et al. (1999) & 0.02 & US & 1 & 0 & 0 & 1 & 0 & 0 & 1990 & 17951 & & & 2 \\
\hline 24 & Delios \& Beamish (1999) & 0.06 & Japan & 0 & 1 & 1 & 0 & 0 & 1 & 1993 & 266 & 4 & 3.8 & 3 \\
\hline 25 & Doukas et al. (1999) & 0.18 & US & 0 & 0 & 0 & 1 & 0 & 1 & 1991 & 144.8 & 2 & 0.9 & 5 \\
\hline
\end{tabular}

Note: All variables are averaged for each paper. 'Coef.' = coefficient of each paper. Country groups: World (1): USA and Europe; World (2): Argentina, Austria, Brazil, Belgium, Chile, Colombia, Finland, France, India, Italy, Japan, Korea, Mexico, Netherlands, Norway, Philippines, Portugal, Spain, Taiwan, UK, USA; (3): $42 \%$ of firm samples from USA and remaining $58 \%$ from other nations. 'C.' $=$ financial crisis. 'C.O' = country of origin. 'E.M' = estimation method. 'P' = measurement of performance. 'S.H' = sample heterogeneity. 'M' = measurement of multinationality. 'T.P' = time period. 'W.1' and 'W.2' = journal weight one and two, respectively. See text for more details about the meaning of each variable. ' $N$ ' indicates number of estimates used from the paper. See text for more details about the meaning of each variable. 
Table 2: List of 51 studies on linear MN-Performance relationships and some of their characteristics (Cont's)

\begin{tabular}{|c|c|c|c|c|c|c|c|c|c|c|c|c|c|c|}
\hline Paper & Reference & Coef. & Countries & C. & C.O & E.M & $\mathbf{P}$ & S.H & $\mathbf{M}$ & T.P & Obs & W.1 & W.2 & $\mathbf{N}$ \\
\hline 26 & Gomes \& Ramaswamy (1999) & 0.01 & US & 0 & 0 & 0 & 0 & 0 & 1 & 1992.5 & 570 & 4 & 3.8 & 1 \\
\hline 27 & Click \& Harrison (2000) & -0.11 & US & 0.4 & 0 & 0 & 0.6 & 0 & 0.6 & 1992.9 & 28789.2 & & & 10 \\
\hline 28 & Geringer et al. (2000) & -0.04 & Japan & 0 & 1 & 0 & 0 & 1 & 0 & 1987 & 891 & 4 & 3.8 & 8 \\
\hline 29 & Zahra et al. (2000) & 0.18 & US & 0 & 0 & 0 & 0 & 0 & 0 & 1993 & 321 & 4 & 3.8 & 2 \\
\hline 30 & Pantzalis (2001) & 0.03 & US & 0 & 0 & 0 & 0 & 0 & 1 & 1990 & 420 & 4 & 3.8 & 8 \\
\hline 31 & Ramírez-Alesón \& Espitia-Escuer (2001) & 0.11 & Spain & 0 & 1 & 0 & 0.5 & 0 & 1 & 1993 & 515 & 3 & 1.7 & 4 \\
\hline 32 & Christophe \& Pfeiffer (2002) & 0.26 & US & 0 & 0 & 0 & 1 & 0 & 1 & 1992 & 7118 & 3 & 2 & 7 \\
\hline 33 & Dastidar (2002) & -0.03 & Japan & 0.1 & 0.7 & 0 & 1 & 0 & 0 & 1994.1 & 1299.6 & & & 61 \\
\hline 34 & Denis et al. (2002) & -0.17 & US & 0.9 & 0 & 0 & 1 & 0 & 0 & 1989.2 & 24656.6 & 4 & 3.8 & 9 \\
\hline 35 & Kotabe et al. (2002) & -0.01 & US & 1 & 0 & 0 & 0 & 0 & 0 & 1990.5 & 294 & 4 & 3.8 & 1 \\
\hline 36 & Qian (2002) & 2.69 & US & 1 & 0 & 0 & 0 & 0 & 0 & 1991 & 355 & 4 & 3.4 & 1 \\
\hline 37 & Capar \& Kotabe (2003) & 0.42 & Germany & 0 & 1 & 0 & 0 & 1 & 0 & 1998 & 243 & 4 & 3.8 & 1 \\
\hline 38 & Contractor et al. (2003) & 0.42 & World (3) & 1 & 0.6 & 0 & 0 & 1 & 1 & 1985.5 & 404 & 4 & 3.8 & 3 \\
\hline 39 & Goerzen \& Beamish (2003) & 0.09 & Japan & 0 & 1 & 0 & 1 & 1 & 1 & 1999 & 580 & 4 & 3.8 & 1 \\
\hline 40 & Ruigrok \& Wagner (2003) & 0.01 & Germany & 0 & 1 & 0 & 0 & 1 & 0 & 1995 & 252 & 3 & 1.7 & 4 \\
\hline 41 & Christophe \& Lee (2004) & -0.34 & US & 0 & 0 & 0 & 1 & 1 & 0.8 & 1999 & 100 & 3 & 2.2 & 6 \\
\hline 42 & Thomas \& Eden (2004) & -0.12 & US & 0 & 0 & 0 & 0.5 & 1 & 0.8 & 1992 & 755 & 1 & 0.6 & 16 \\
\hline 43 & Lu \& Beamish (2004) & -0.57 & Japan & 1 & 1 & 0 & 0.5 & 0 & 1 & 1991.5 & 17868 & 4 & 3.8 & 2 \\
\hline 44 & Andersen (2005) & 0.98 & US & 0 & 0 & 0 & 0 & 1 & 1 & 1998 & 603.8 & & & 6 \\
\hline 45 & Li (2005) & 0.00 & US & 0 & 0 & 0 & 0 & 0 & 0 & 1999 & 689 & 3 & 1.7 & 2 \\
\hline 46 & Hitt et al. (2006) & 0.05 & US & 0 & 0 & 0 & 0 & 1 & 1 & 1995.5 & 412 & 4 & 19 & 4 \\
\hline 47 & Castellani \& Zanfei (2007) & 0.13 & Italy & 0 & 1 & 0.7 & 0 & 1 & 1 & 1995 & 2942.3 & 3 & 2.4 & 3 \\
\hline 48 & Ruigork et al. (2007) & -0.14 & US & 0 & 1 & 0 & 0 & 1 & 0 & 2001.5 & 696 & 3 & 1.4 & 1 \\
\hline 49 & Andersen (2008) & 0.04 & US & 0 & 0 & 0 & 0 & 1 & 1 & 1998 & 443 & & & 5 \\
\hline 50 & Pangarkar (2008) & 0.02 & Singapore & 0 & 1 & 0 & 0 & 0 & 0 & 2004 & 500 & 3 & 2.5 & 1 \\
\hline 51 & Qian et al. (2008) & 0.24 & US & 0 & 0 & 0 & 0 & 1 & 0 & 1998 & 770 & 4 & 3.8 & 4 \\
\hline
\end{tabular}

Note: All variables are averaged for each paper. 'Coef.' = coefficient of each paper. Country groups: World (1): USA and Europe; World (2): Argentina, Austria, Brazil, Belgium, Chile, Colombia, Finland, France, India, Italy, Japan, Korea, Mexico, Netherlands, Norway, Philippines, Portugal, Spain, Taiwan, UK, USA; (3): $42 \%$ of firm samples from USA and remaining $58 \%$ from other nations. 'C.' = financial crisis. 'C.O' = country of origin. 'E.M' = estimation method. 'P' = measurement of performance. 'S.H' = sample heterogeneity. ' $\mathrm{M}$ ' = measurement of multinationality. 'T.P' = time period. 'W.1' and 'W.2' = journal weight one and two, respectively. See text for more details about the meaning of each variable. See text for more details about the meaning of each variable. 'N' indicates number of estimates used from the paper. 
Table 3: List of 16 studies on curvilinear MN-Performance relationships and some of their characteristics

\begin{tabular}{|c|c|c|c|c|c|c|c|c|c|c|c|c|}
\hline Paper & Reference & Shapes & Countries & C.O & P. & S.H. & M. & T.P. & Obs & W.1 & W.2 & $\mathbf{N}$ \\
\hline 1 & Hitt et al. (1997) & 1 & US & 0 & 0 & 0 & 0 & 1989 & 293 & 4 & 3.8 & 2 \\
\hline 2 & Gomes \& Ramaswamy (1999) & 1 & US & 0 & 0 & 0 & 1 & 1992.5 & 570 & 4 & 3.8 & 1 \\
\hline 3 & Lu \& Beamish (2001) & 0 & Japan & 1 & 0 & 0 & 1 & 1991.5 & 1450.5 & 4 & 3.8 & 16 \\
\hline 4 & Qian (2002) & 1 & US & 0 & 0 & 0 & 0 & 1991 & 355 & 4 & 3.4 & 1 \\
\hline 5 & Capar \& Kotabe (2001) & 0 & Germany & 1 & 0 & 1 & 0 & 1998 & 243 & 4 & 3.8 & 1 \\
\hline 6 & Contractor et al. (2003) & 0 & World (1) & 0.6 & 0 & 1 & 1 & 1985.5 & 485 & 4 & 3.8 & 2 \\
\hline 7 & Ruigrok \& Wagner (2003) & 0 & Germany & 1 & 0 & 1 & 0 & 1995 & 252 & 3 & 1.7 & 4 \\
\hline 8 & Christophe \& Lee (2004) & 0.67 & US & 0 & 1 & 1 & 0.7 & 1999 & 100 & 3 & 2.2 & 3 \\
\hline 9 & Thomas \& Eden (2004) & 0 & US & 0 & 0.5 & 1 & 1 & 1992 & 755 & 1 & 0.6 & 4 \\
\hline 10 & Lu \& Beamish (2001) & 0 & Japan & 1 & 0.5 & 0 & 1 & 1991.5 & 17868 & 4 & 3.8 & 2 \\
\hline 11 & Li \& Qian (2005) & 1 & US & 0 & 0 & 1 & 1 & 1995 & 167 & 1 & 0.7 & 4 \\
\hline 12 & $\operatorname{Li}(2005)$ & 0 & US & 0 & 0 & 0 & 0 & 1999 & 1848 & 3 & 1.7 & 2 \\
\hline 13 & $\operatorname{Li}(2007)$ & 1 & US & 0 & 0 & 1 & 1 & 1998 & 485 & 1 & 0.7 & 4 \\
\hline 14 & Ruigrok et al. (2007) & 1 & US & 1 & 0 & 1 & 0 & 2001.5 & 696 & 3 & 1.4 & 1 \\
\hline 15 & Andersen (2008) & 0.25 & US & 0 & 0 & 1 & 1 & 1998 & 420.8 & & & 4 \\
\hline 16 & Qian et al. (2008) & 1 & US & 0 & 0 & 1 & 0 & 1998 & 770 & 4 & 3.8 & 4 \\
\hline
\end{tabular}

Note: All variables are averaged for each paper. 'Shapes' is a dummy variable that takes value one if the estimates in the paper indicate inverted U-shaped curve. Country groups: World (1): $42 \%$ of firm sample from USA and remaining $58 \%$ from other nations. 'C.O.' = country of origin. 'P.' = measurement of performance. 'E.M.' = estimation method. 'S.H.' = sample heterogeneity. 'M.' = measurement of multinationality. 'T.P' = time period. 'W.1' and 'W.2' are journal weight one and two, respectively. See text for more details about the meaning of each variable. ' $N$ ' indicates number of estimates used from the paper. 
Table 4: Descriptive Statistics

\begin{tabular}{|c|c|c|c|}
\hline Variable & Mean & Std. Dev & $\mathbf{N}$ \\
\hline \multicolumn{4}{|c|}{ The Linear MN-Performance Relationship } \\
\hline Coefficient & 0.16 & 1.15 & 315 \\
\hline Financial Crisis & 0.16 & 0.37 & 315 \\
\hline Country of Origin & 0.26 & 0.43 & 315 \\
\hline Estimation Method & 0.07 & 0.26 & 315 \\
\hline Measurement of Multinationality & 0.59 & 0.49 & 315 \\
\hline Sample Heterogeneity & 0.43 & 0.5 & 315 \\
\hline Measurement of Performance & 0.5 & 0.5 & 315 \\
\hline Time Period & 1988.16 & 7.58 & 315 \\
\hline No. Observation & 2631.71 & 6831.86 & 315 \\
\hline St. Error & 0.21 & 0.53 & 192 \\
\hline Weight1 & 3.18 & 1.22 & 231 \\
\hline Weight2 & 3.03 & 2.48 & 231 \\
\hline \multicolumn{4}{|c|}{ The Curvilinear MN-Performance Relationships } \\
\hline Shape & 0.36 & 0.49 & 55 \\
\hline Country of Origin & 0.46 & 0.49 & 55 \\
\hline Estimation Method & 0 & 0 & 55 \\
\hline Measurement of Performance & 0.11 & 0.31 & 55 \\
\hline Sample Heterogeneity & 0.56 & 0.5 & 55 \\
\hline Measurement of Multinationality & 0.71 & 0.46 & 55 \\
\hline Time Period & 1994.15 & 3.68 & 55 \\
\hline NO. Observation & 1413.8 & 3279.83 & 55 \\
\hline Weight 1 & 3.1 & 1.24 & 51 \\
\hline Weight 2 & 2.67 & 1.36 & 51 \\
\hline
\end{tabular}

Note: 'Coefficient' is the estimate of linear MN-Performance relationships in the study; 'Financial Crisis' is a dummy variable that takes value one if the survey year of the paper is in the period of financial crisis or one year after, otherwise zero; 'Country of Origin' is a dummy variable equal to one if the sample draws from non-US firms; 'Estimation Method' is a dummy variable if the paper adopts non-regression analysis; 'Measurement of Multinationality' is a dummy variable equal to one if the study uses the ratio of foreign to total sales to measure multinationality; 'Sample Heterogeneity' is a dummy variable equal to one if the sample of study is only large firms; 'Measurement of Performance' is a dummy variable equal to one if firm performance is based on market-based indicators; 'Time Period' is survey year of the study; 'No. Observations' is the average number of observations in the study; 'St. Error' is the standard error of the estimate of MN-Performance relationships in each study; 'Shapes' is a dummy variable that takes value one if the estimates in the paper indicate an inverted U-shaped curve. (Journal) 'Weight1' is an indication of the total weight assigned to the paper by the citation impact from Harvey et al. (2008). (Journal) 'Weight2' represents an average across the various rankings, including Aston ranking 2006, Kent ranking 2005, Cranfield ranking 2005, Durham ranking 2006 and citation impact from Harvey et al. (2008). Also, see text in Methodology section for more details on each variable. 
Table 5: Meta-Analysis Regression on linear MN-Performance relationships

\begin{tabular}{|c|c|c|c|c|c|c|}
\hline & No-Weight & Weight1 & Weight2 & No-Weight & Weight1 & Weigth2 \\
\hline & (1) & (2) & (3) & (4) & (5) & (6) \\
\hline \multirow[t]{2}{*}{ Financial Crisis } & .063 & $.278 * *$ & $.254 * *$ & .028 & .059 & .024 \\
\hline & $(.099)$ & $(.127)$ & $(.119)$ & $(.074)$ & $(.094)$ & $(.092)$ \\
\hline \multirow[t]{2}{*}{ Country of Origin } & $.527 * *$ & $1.074 * * *$ & $1.038 * * *$ & $.457 * *$ & $.465 * *$ & $.368^{*}$ \\
\hline & $(.227)$ & $(.387)$ & $(.384)$ & $(.197)$ & $(.190)$ & $(.195)$ \\
\hline \multirow[t]{2}{*}{ Estimation Method } & $-.523 * *$ & $-.732 * *$ & $-.834 * *$ & & & \\
\hline & $(.239)$ & $(.297)$ & $(.326)$ & & & \\
\hline \multirow[t]{2}{*}{ M. of Multinationality } & -.112 & $-.434 * *$ & $-.352 * *$ & -.111 & $-.331 *$ & -.066 \\
\hline & $(.112)$ & $(.197)$ & $(.176)$ & $(.123)$ & $(.185)$ & $(.147)$ \\
\hline \multirow[t]{2}{*}{ Sample Heterogeneity } & .157 & -.035 & .092 & -.285 & $-673 * *$ & $-.368 *$ \\
\hline & $(.146)$ & $(.171)$ & $(.144)$ & $(.180)$ & $(.262)$ & $(.196)$ \\
\hline \multirow[t]{2}{*}{ M. of Performance } & $-.270 *$ & -.051 & -.149 & $-.418 * *$ & $-.578 * * *$ & $-.639 * * *$ \\
\hline & $(.147)$ & $(.157)$ & $(.156)$ & $(.165)$ & $(.197)$ & $(.210)$ \\
\hline \multirow[t]{2}{*}{ Time Period } & $-.034 * *$ & $-.045 * * *$ & $-.041 * * *$ & $-.026 * *$ & $-.034 * * *$ & $-.023 * *$ \\
\hline & $(.015)$ & $(.017)$ & $(.016)$ & $(.011)$ & $(.0 .12)$ & $(.009)$ \\
\hline \multirow[t]{2}{*}{$\sqrt{\text { No.observation }}$} & -.0002 & $-.005 * *$ & $-.005 * * *$ & .0004 & -.001 & .0007 \\
\hline & $(.001)$ & $(.002)$ & $(.002)$ & $(.0008)$ & $(.0 .01)$ & $(.001)$ \\
\hline \multirow[t]{2}{*}{ St. Error } & & & & $1.944 * * *$ & $2.043 * * *$ & $2.072 * * *$ \\
\hline & & & & $(.195)$ & $(.140)$ & $(.138)$ \\
\hline Obs. & 315 & 231 & 231 & 192 & 174 & 174 \\
\hline $\mathrm{R} 2$ & .103 & 0.198 & 0.216 & 0.72 & 0.799 & 0.815 \\
\hline
\end{tabular}

Note: The dependent variable for each regression is an estimate of the relationship between multinationality and firm performance from the studies considered in this paper. See the notes to table 4 for more details of each variable. Significance levels: *: $0.10 ; * *: 0.05 ; * *: 0.01$. 
Table 6: Meta-Analysis Regression on curvilinear MN-Performance relationships

\begin{tabular}{|c|c|c|c|c|c|c|}
\hline & No-Weight & Weight1 & Weight2 & No-Weight & Weight1 & Weight2 \\
\hline & (1) & (2) & (3) & (4) & $(5)$ & (6) \\
\hline Country of Origin & $\begin{array}{c}.498 * * * \\
(.097)\end{array}$ & $\begin{array}{c}-.600 * * \\
(.124)\end{array}$ & $\begin{array}{c}-.469 * * * \\
(.092)\end{array}$ & $\begin{array}{c}-1.277 * * * \\
(.222)\end{array}$ & $\begin{array}{c}-.776 * * * \\
(.178)\end{array}$ & $\begin{array}{c}.-574 * * * \\
(.183)\end{array}$ \\
\hline M. of Multinationality & $\begin{array}{c}-.220^{* *} \\
(.095)\end{array}$ & $\begin{array}{l}-.036 \\
(.059)\end{array}$ & $\begin{array}{l}-.030 \\
(.041)\end{array}$ & $\begin{array}{c}-1.055^{* * *} \\
(.283)\end{array}$ & $\begin{array}{c}-.420 * * * \\
(.146)\end{array}$ & $\begin{array}{c}-.305 * * \\
(.136)\end{array}$ \\
\hline Sample Heterogeneity & $\begin{array}{c}.003 \\
(.135)\end{array}$ & $\begin{array}{c}-.106 * * \\
(.053)\end{array}$ & $\begin{array}{c}-.083 * * \\
(.037)\end{array}$ & $\begin{array}{c}.891 * * * \\
(.333)\end{array}$ & $\begin{array}{l}.283 * * \\
(.131)\end{array}$ & $\begin{array}{l}.199 * \\
(.113)\end{array}$ \\
\hline M. of Performance & $\begin{array}{c}-.241 * \\
(.130)\end{array}$ & $\begin{array}{c}-.726 * * * \\
(.228)\end{array}$ & $\begin{array}{c}-.544 * * * \\
(.167)\end{array}$ & & & \\
\hline Time Period & $\begin{array}{l}.016 \\
(.015)\end{array}$ & $\begin{array}{c}.060 * * * \\
(.020)\end{array}$ & $\begin{array}{c}.043 * * * \\
(.014)\end{array}$ & $\begin{array}{l}.020 \\
(.018)\end{array}$ & $\begin{array}{l}.038 \\
(.015)\end{array}$ & $\begin{array}{l}.025 * * \\
(.011)\end{array}$ \\
\hline$\sqrt{\text { No.Observation }}$ & $\begin{array}{c}-.014 * * * \\
(.003)\end{array}$ & $\begin{array}{c}-.027 * * * \\
(.007)\end{array}$ & $\begin{array}{c}-.021 * * * \\
(.005)\end{array}$ & $\begin{array}{c}-.011 * \\
(.006)\end{array}$ & $\begin{array}{c}-.019 * * * \\
(.004)\end{array}$ & $\begin{array}{c}-014 * * * \\
(.004)\end{array}$ \\
\hline Obs. & 55 & 51 & 51 & 35 & 31 & 31 \\
\hline Pseudo R2 & 0.55 & 0.77 & 0.83 & 0.46 & 0.71 & 0.80 \\
\hline
\end{tabular}

Note: The dependent variable for each regression is the shape of curvilinear outcome from the studies on curvilinear MN-Performance relationship; See the notes to table 4 for more details of each variable. Significance levels: *: $0.10 ; * *: 0.05 ; * * *: 0.01$. 
Table 7: Meta-Analysis Regression on curvilinear MN-Performance relationships, including cubic term of multinationality

\begin{tabular}{lccc}
\hline & No-Weight & Weight1 & Weight2 \\
\cline { 2 - 4 } & $(4)$ & $(5)$ & $(6)$ \\
\hline Cubic Order & -.142 & .124 & .047 \\
& $(.143)$ & $(.126)$ & $(.099)$ \\
Country of Origin & $-1.175^{* * *}$ & $-.875^{* * *}$ & $-.740^{* * *}$ \\
& $(.140)$ & $(.208)$ & $(.232)$ \\
M. of Multinationality & $-.919^{* * *}$ & $-.704^{* * *}$ & $-.610^{* *}$ \\
& $(.259)$ & $(.253)$ & $(.265)$ \\
Sample Heterogeneity & $.834^{* * *}$ & $.508^{*}$ & $.488^{*}$ \\
& $(.220)$ & $(.261)$ & $(.258)$ \\
Time Period & .0220 & .0161 & .006 \\
& $(.019)$ & $(.015)$ & $(.010)$ \\
$\sqrt{\text { No.Observation }}$ & $-.011 * *$ & $-.012^{* *}$ & $-.008^{* *}$ \\
& $(.006)$ & $(.005)$ & $(.003)$ \\
Obs. & 35 & 35 & 35 \\
Pseudo R2 & 0.49 & 0.67 & 0.74 \\
\hline \hline
\end{tabular}

Note: The dependent variable for each regression is the shape of curvilinear outcome from the studies on curvilinear MN-Performance relationship. We have now assigned 0.5 to the unpublished paper to increase the degree of freedom; otherwise degree of freedom is zero. 'Cubic Order' is a dummy equal to one for those papers which include a cubic term. See the notes to table 4 for more details of each variable. Significance levels: *: $0.10 ; * *: 0.05 ; * * *: 0.01$. 
Table 8: Publication Bias

\begin{tabular}{lccc}
\hline & No-Weight & Weight1 & Weigth2 \\
\cline { 2 - 4 } & $(1)$ & $(2)$ & $(3)$ \\
\hline$\sqrt{\text { No.Observation }}$ & $.105^{* * *}$ & $.106^{* * *}$ & $.113^{* * *}$ \\
Financial Crisis & $(.012)$ & $(.010)$ & $(.010)$ \\
& $1.774^{* * *}$ & $2.348^{* * *}$ & $2.318^{* * *}$ \\
Country of Origin & $.570)$ & $(.545)$ & $(.552)$ \\
& -.596 & $-1.433^{* *}$ & $-1.763^{* *}$ \\
Estimation method & $. .585)$ & $(.593)$ & $(.685)$ \\
& $-1.889^{*}$ & $-2.616^{* * *}$ & $-2.669^{* *}$ \\
Measurement of Multinationality & $(.994)$ & $(1.007)$ & $(1.249)$ \\
& $-1.414^{* * *}$ & $-1.816^{* * *}$ & $-1.323^{* * *}$ \\
Sample Heterogeneity & $.498)$ & $(.576)$ & $(.629)$ \\
& $1.224 * * *$ & $1.873^{* * *}$ & $2.418^{* * *}$ \\
Measurement of Performance & $(.403)$ & $(.475)$ & $(.497)$ \\
& -0.046 & .085 & -.204 \\
Time Period & $.333)$ & $(.389)$ & $(.383)$ \\
& .025 & .020 & $.042 *$ \\
St. Error & $(.023)$ & $(.023)$ & $(.022)$ \\
& .077 & .073 & .141 \\
Obs. & $(.314)$ & $(.280)$ & $(.261)$ \\
R2 & 174 & 174 & 174 \\
\hline \hline
\end{tabular}

Note: The dependent variable for each regression is the t-ratio from the studies considered in this paper; ' $\sqrt{\text { No.Observation }}$, is the square root of average number of observations in the study. See the notes to table 4 for more details of each variable. Significance levels: *: $0.10 ; * *: 0.05 ; * * *: 0.01$. 